\title{
The Effect of Negotiated Syllabus on EFL Learners' Writing Ability and Self-efficacy
}

\author{
Gholam-Reza Abbasian \\ Imam Ali University \& IAU, South Tehran Branch, Tehran, Iran \\ Parvin Malardi \\ Department of English, South Tehran Branch, Islamic Azad University, Tehran, Iran
}

\begin{abstract}
Language curriculum and syllabus play crucial roles in finding some ways to develop and facilitate the process of learning English. Learner involvement based on variety of mechanisms has recently received momentum in ESL/EFL education in line with this, this study attempted to unravel the effects of negotiation syllabus on both skill acquisition and affection change: writing ability and writing self-efficacy based on data gathered following the treatment to 62 Iranian EFL adult learners. Exercising conventional writing instruction to a control group and negotiation syllabus- based one to an experimental group, the study unraveled that skill acquisition (i.e., writing ability) was more significantly affected in light of the treatment than the self-efficacy trait. The general language proficiency was not also much affected following the experiment. Impressionistic analyses proved that the negotiated syllabus leads to more learner autonomy though.
\end{abstract}

Index Terms — syllabus, negotiated syllabus, self-efficacy, writing skill, writing self-efficacy

\section{INTRODUCTION}

Etymologically syllabus means a label or table of contents. White (1988) viewed syllabus as the specification and ordering of content of a course. However, the foundation for a good course is a good syllabus.A course syllabus can serve as a highly efficient facilitator of student learning (Grunert, 1997; Pastorino, 1999) .Moreover, a well-designed syllabus can increase the likelihood of student success in class.

Several distinct types of language teaching syllabi exist, which may be implemented in various teaching situations. The traditional interpretation of syllabus focuses on outcomes rather than process and it was the role of the teacher to make decisions (Breen \& Littlejohn, 2000). The traditional syllabus was a teaching plan, usually based on a textbook, which defined how the course was to be instructed. The classroom was seen as a closed system with its books and a fixed program (Blackman, 2008). The teacher chose the program content and imposed it to the students. However, according to (Clarke, 1991), "the communicative era of the language teaching has seen enormous developments in the area of syllabus design" (p.13). Modern education places great value on the development of the learners' humanistic qualities and the associated affective factors. The syllabus designer, instead of prescribing learning content, provides teacher and learners a frame work to build their own on-going syllabus in the classroom and the students are responsible for their own learning. They tend to give students control, choice, and a more active role in their learning process. Therefore, the negotiated syllabuses were proposed as a reference point for teachers who wished to engage students into the classroom.

Theoretically, syllabuses are of two types: product-oriented syllabus and process-oriented syllabus. Productoriented syllabus focuses on what the learners will know as a result at the end of instruction session. Nunan (1994) states that "product-oriented syllabuses aiming at knowledge and skills which learners should gain as a result of instruction" (p. 27). Compared with the product syllabuses, the process syllabuses have attached more importance to the process of language learning and focus on the pedagogical processes leading to the language outcomes. An important characteristic of the process syllabus is that "it is an infrastructure rather than a learning plan, with the syllabus designer no longer pre-selecting learning content, but providing a framework for teacher and learners to create their own ongoing syllabus in the classroom" (Breen 1987a, p. 166), and learners are engaged in evolving the syllabus. Studentteacher and student-student negotiation of content and direction is an essential section of the process approach, but negotiation of meaning within that process is also a critical characteristic (Long \& Crookes 1993; Stevick, 1976, 1980). Breen (2000) explains that process syllabus see learning as interactive, negotiated, and reflective. Negotiation provides a context for learners to articulate and refine their prior understandings, purposes and intentions for new learning.

Negotiated Syllabus and Writing Skill

Over recent years, interest in the concept of negotiation has come in the language teaching. Negotiated syllabus means regularly involving the learners in decision making regarding the goals, content, presentation, and assessment of the course (Breen 1987; Clarke 1991).In this kind of syllabus, learners learn through democratic decision-making. In negotiation-based approaches, teacher and learners come to agreement on what to learn and how to learn (Tuan, 2011). Proponents of this innovation believe that the syllabus which comes out from the negotiation process is more flexible 
and relevant to learners' needs and hence more motivating and allows learners to play a more informed and selfdirective purpose in their learning (Bloor \& Bloor, 1988; Boomer et al., 1992; Breen \& Littlejohn, 2000; Nunan, 1992, 1999; Nunan, 1988; Tudor, 1996). Meanwhile, "negotiation provides a context in which opportunities exist for learner to articulate and, thereby, refine their prior understanding, purposes and intentions as reference points for new learning" (Breen \& Littlejohn, 2000,p. 24) and allows for changing the perceptions in the learners, without specifying particular content, methodology, structure, or grammar.

In relation to writing domain, Lo and Hyland (2007) suggested that "one way of enhancing students' motivation and engagement to write is to provide opportunities for them to engage at a more meaningful level with the language through refocusing their writing classes to make them relevant to their social and cultural context as well as designing writing tasks which have meaning and interest to them and offer opportunities for social interaction and selfexpression" (p.221).

\section{Self-Efficacy and Writing Skill}

Self-efficacy is "people's beliefs about their capacities to produce performances that affect events affecting their lives" (Bandura, 1995, p. 434). It is the beliefs one has about their capacities to direct and execute the courses of action needed to produce given attainments (Bandura, 1997). More than two decades of research have clearly shown that selfefficacy influences academic motivation, learning and achievement (Pajares \& Schunk, 2005; Zimmerman, 2000). Recently, self-beliefs about writing have received more attention. Writing self-efficacy is self-beliefs that underlie student motivation in writing. In other words, it is defined as the belief in one's ability to write. According to Hayes (1996) in writing skill; cognitive components are associated with affective and motivational factors which can affect the students' writing. Writing self-efficacy is one's personal belief in his ability to write. Within the motivational component, self-efficacy has a significant effect on writing (Pajares\&Valiente, 2006). Learners with high self-efficacy see difficult writing tasks as challenging and work attentively to master them (Lavelle, 2005; Lavelle, 2006). Failure, self-doubts, learned helplessness, poor self-efficacy and poor motivation will negatively affect a student's ability to write well (Sawyer, Graham \& Harris, 1992).

\section{The Problem and Purpose}

Contrary to commonality of various syllabuses, the problem is which syllabus works most effectively. What usually happens in EFL classes is that teachers make decisions and determine what students are supposed to do and how they are expected to do them without almost any negotiation with and involvement of students. Since improving writing skills has usually been a major concern for EFL learners, the present study reasoned that implementation of a negotiated syllabus would likely improve writing achievement and learner's self-efficacy because students would be allowed to make choices. It was assumed that a direct negotiation in a writing class would enhance enthusiasm on the part of students for practicing writing and, accordingly, develop a more favorable attitude to learning English in general, and more positive perceptions of their own writing ability in particular.Considering the interrelationship of EFL negotiated syllable and writing self-efficacy and the effects of the first variable on the second, this study was designed to verify the reported cases of interrelationship and to respond to a fraction of doubts and concerns in the literature by investigating the relationship between negotiated syllabus and writing self-efficacy, and more specifically exploring the effect of using negotiated syllabus on Iranian EFL learners' both writing ability and writing self-efficacy. To tackle these issues, the study designed in the form of quasi-experimental research to address them in the form of two separate research questions converted into respective null hypotheses assuming that a negotiated syllabus does not have any significant effect neither on developing EFL learners' writing ability nor their writing self-efficacy.

\section{METHODOLOGY}

\section{Participants}

Sixty two Iranian male and female intermediate-level Iranian EFL learners ranged 20-30 in terms of age took part in this study. They were doing their associate diploma at Iranian University of Applied Science in Translation of Legal Deeds and Documents. The participants were intact groups. However, the PET was administered prior to treatment to make sure of their language proficiency.

\section{Materials}

Four sets of materials were employed for the purpose of this research.

1. The Preliminary English Test (PET): before and after the treatment, The PET was administered in order to prove that the two groups enjoyed the same level of general language proficiency and compare learners' language ability.

2. Writing Self-Efficacy Questionnaire: Before and after the treatment writing self-efficacy questionnaire was conducted in order to evaluate individuals writing self-efficacy. (The reliability indices for the Pretest and posttest of self-efficacy are .88 and .81 respectively.)

3. Writing Tests: Three writing tests administered to the experimental group in the sessions 4, 6 and 8 for observing any changes in the learners' writing achievement.

4. Researcher-made Writing Post-Test: a researcher-made writing test administered to all the groups at the end of the course.

\section{Procedures}


Having received the pre-treatment instruments, both experimental group and control group attended an English writing course which lasted for 10 educational sessions (1hour and a half a day, two days a week). The control group received conventional writing instruction while the experimental group received the treatment, which was based on the negotiated syllabus. The learners in experimental group were allowed to express own ideas and goals about the course. The students were asked to comment on the learning program (including the activities and the way of assessment), their achievements and progress, the way of teaching and learning. The content of the materials and methodology were also negotiated. The teacher and learners came to agreement on what to learn. Teacher' main goal was to encourage learners to learn cooperatively and learners should be actively involved in this process. Along with the teacher allowed students peer correction. After the treatment, the PET was administered to measure the change in participants' language proficiency. Then, the writing self-efficacy questionnaire was administered to measure the change in participants' writing self-efficacy. Meanwhile, researcher-made writing post-test administered to evaluate the participants' writing.

\section{RESULTS AND DATA ANALYSIS}

\section{Preliminary Analysis (normality check)}

As displayed in Table 1 all of the ratios of skewness and kurtosis over their respective standard errors are within the ranges of $+/-1.96$. Thus, it can be concluded that the tests employed in this study do not show any marked deviations from normality, hence the results were justified to be analyzed parametrically.

TABLE 1

NORMALITY TESTS

\begin{tabular}{|c|c|c|c|c|c|c|c|}
\hline \multirow{2}{*}{\multicolumn{2}{|c|}{ GROUP }} & \multicolumn{3}{|c|}{ Skewdness } & \multicolumn{3}{|l|}{ Kurtosis } \\
\hline & & \multirow{2}{*}{$\begin{array}{l}\text { Statistic } \\
-0.48\end{array}$} & \multirow{2}{*}{$\begin{array}{l}\text { Std. Error } \\
0.46\end{array}$} & \multirow{2}{*}{$\begin{array}{l}\text { Normality } \\
\underline{-1.06} \\
\end{array}$} & \multirow{2}{*}{$\begin{array}{l}\text { Statistic } \\
0.83\end{array}$} & \multirow{2}{*}{$\begin{array}{l}\text { Std. Error } \\
0.89\end{array}$} & \multirow{2}{*}{$\begin{array}{l}\text { Normality } \\
\underline{0.93}\end{array}$} \\
\hline \multirow{5}{*}{ EXPERIEMNTAL } & PRETEST & & & & & & \\
\hline & POSTTEST & -0.65 & 0.46 & -1.43 & 0.19 & 0.89 & $\overline{0.21}$ \\
\hline & TEACHERMADE & -0.40 & 0.46 & -0.89 & -0.68 & 0.89 & -0.76 \\
\hline & $\begin{array}{l}\text { PRE } \\
\text { SELF-EFFICACY }\end{array}$ & 0.02 & 0.46 & $\underline{0.03}$ & -1.01 & 0.89 & $\underline{-1.14}$ \\
\hline & $\begin{array}{l}\text { POST } \\
\text { SELF-EFFICACY }\end{array}$ & 0.29 & 0.46 & $\underline{0.63}$ & 1.24 & 0.89 & $\underline{1.40}$ \\
\hline \multirow{5}{*}{ CONTROL } & PRETEST & -0.48 & 0.40 & -1.22 & -0.88 & 0.78 & -1.13 \\
\hline & POSTTEST & -0.42 & 0.40 & -1.06 & -1.12 & 0.78 & -1.44 \\
\hline & TEACHERMADE & -0.06 & 0.40 & -0.14 & -1.43 & 0.78 & -1.84 \\
\hline & $\begin{array}{l}\text { PRE } \\
\text { SELF-EFFICACY }\end{array}$ & 0.48 & 0.39 & $\underline{1.23}$ & -0.81 & 0.77 & $\underline{-1.05}$ \\
\hline & $\begin{array}{l}\text { POST } \\
\text { SELF-EFFICACY }\end{array}$ & 0.23 & 0.39 & $\underline{0.58}$ & -0.64 & 0.77 & $\underline{-0.83}$ \\
\hline
\end{tabular}

\section{Language Proficiency Measure}

An independent t-test was run to compare the mean scores of the experimental and control groups on the PET in order to prove that the two groups enjoyed the same level of general language proficiency prior to the administration of the negotiated syllabus to the experimental group. As displayed in Table 2 the experimental group with a mean score of 10 performed better than the control group $(\mathrm{M}=8.95)$ on the PET.

TABLE 2:

DESCRIPTIVE STATISTICS OF PET BY GROUPS

\begin{tabular}{|l|l|l|l|l|}
\hline GROUP & $\mathrm{N}$ & Mean & Std. Deviation & Std. Error Mean \\
\hline EXPERIEMNTAL & 26 & 10.0077 & 2.01374 & 39493 \\
\hline CONTROL & 36 & 8.9539 & 2.67102 & 44517 \\
\hline
\end{tabular}

The t-observed value of 1.69 at 60 degrees of freedom is lower than the critical value of 2 at .05 levels of significance (Table 3). Based on these results, it can be concluded that there was not any significant difference between the mean scores of the experimental and control groups on the PET. Thus, it can be claimed that both groups were homogenous in terms of their general language proficiency prior to the main study. It should be noted that the assumption of homogeneity of variances was met. The probability associated with the Levene's $\mathrm{F}=2.45$, i.e. .12 was higher than .05 .

TABLE 3:

INDEPENDENT T-TEST BY GROUPS

\begin{tabular}{|c|c|c|c|c|c|c|c|c|}
\hline & \multicolumn{2}{|c|}{$\begin{array}{l}\text { Levene's Test for } \\
\text { Equalityof } \\
\text { Variances }\end{array}$} & \multicolumn{6}{|c|}{ t-test for Equality of Means } \\
\hline & \multirow[t]{2}{*}{$\mathrm{F}$} & \multirow[t]{2}{*}{ Sig. } & \multirow[t]{2}{*}{$\mathrm{t}$} & \multirow[t]{2}{*}{ df } & \multirow[t]{2}{*}{$\begin{array}{l}\text { Sig. (2- } \\
\text { tailed) }\end{array}$} & \multirow[t]{2}{*}{\begin{tabular}{|l|l} 
Mean Difference & Std. Error \\
Difference
\end{tabular}} & \multicolumn{2}{|c|}{$\begin{array}{l}95 \% \text { Confidence Interval } \\
\text { of the Difference }\end{array}$} \\
\hline & & & & & & & Lower & Upper \\
\hline Equalvariances assumed & 2.45 & 0.12 & 1.69 & 60.00 & 0.10 & 0.62 & -0.19 & 2.30 \\
\hline Equal variances not assumed & & & 1.77 & 59.86 & 0.08 & 0.60 & -0.14 & 2.24 \\
\hline
\end{tabular}

\section{Self-Efficacy Measure}


An independent t-test was run to compare the mean scores of the experimental and control groups on the pretest of self-efficacy in order to prove that the two groups enjoyed the same level of self-efficacy prior to the implementation of the negotiated syllabus to the experimental group. As displayed in Table 4, the control group with a mean score of 74.57 performed better than the experimental group $(M=80.11)$ on the pretest of self-efficacy.

TABLE 4:

DESCRIPTIVE STATISTICS OF SELF-EFFICACY MEASURE BY GROUPS

\begin{tabular}{|l|l|l|l|l|}
\hline GROUP & $\mathrm{N}$ & Mean & Std. Deviation & Std. Error Mean \\
\hline Experimental & 26 & 74.5769 & 10.13577 & 1.98779 \\
\hline Control & 36 & 80.1111 & 6.96020 & 1.16003 \\
\hline
\end{tabular}

The t-observed value of 2.55 at 60 degrees of freedom is lower than the critical value of 2.66 at .01 levels of significance (Table 5). Based on the results it could be concluded that there was not any significant difference between the mean scores of the experimental and control groups on the pretest of self-efficacy. Thus, it can be claimed that both groups were homogenous in terms of their self-efficacy prior to the main study. It should be noted that the assumption of homogeneity of variances was met. The probability associated with the Levene's $F=5.73$, i.e. .02 was lower than .05 . That is why level of significance (alpha level) is reduced from .05 to .01.

TABLE 5:

INDEPENDENT T-TEST OF SELF-EFFICACY MEASURE BY GROUPS

\begin{tabular}{|c|c|c|c|c|c|c|c|c|c|}
\hline & \multicolumn{2}{|c|}{$\begin{array}{l}\text { Levene's Test for } \\
\text { Equality of Variances }\end{array}$} & \multicolumn{7}{|c|}{ t-test for Equality of Means } \\
\hline & \multirow[t]{2}{*}{$\mathrm{F}$} & \multirow[t]{2}{*}{ Sig. } & \multirow[t]{2}{*}{$t$} & \multirow[t]{2}{*}{ df } & \multirow[t]{2}{*}{ Sig. (2-tailed) } & \multirow[t]{2}{*}{$\begin{array}{l}\text { Mean } \\
\text { Difference }\end{array}$} & \multirow[t]{2}{*}{$\begin{array}{l}\text { Std. Error } \\
\text { Difference }\end{array}$} & \multicolumn{2}{|c|}{$\begin{array}{l}95 \% \text { Confidence Interval } \\
\text { of the Difference }\end{array}$} \\
\hline & & & & & & & & Lower & Upper \\
\hline Equal variances assumed & 5.73 & .02 & 2.55 & 60 & .013 & 5.53 & 2.16 & 1.19 & 9.87 \\
\hline Equal variances not assumed & & & 2.40 & 41.49 & .021 & 5.53 & 2.30 & .88 & 10.18 \\
\hline
\end{tabular}

\section{Investigation of the First Research Question}

In order to answer the first research question "Does a negotiated syllabus have any significant effect on developing EFL learners' writing ability?", an independent t-test was run to compare the mean scores of the experimental and control groups on the writing in order to investigate the effect of the negotiated syllabus on the improvement of the writing ability of the experimental group. As displayed in Table 6, the experimental group with a mean score of 12.76 performed better than the control group $(\mathrm{M}=9.49)$ on the writing test.

TABLE 6:

DESCRIPTIVE STATISTICS OF WRITING TEST

\begin{tabular}{|l|l|l|l|l|}
\hline GROUP & $\mathrm{N}$ & Mean & Std. Deviation & Std. Error Mean \\
\hline Experimental & 26 & 12.7692 & 1.40876 & .27628 \\
\hline Control & 36 & 9.4972 & 2.99480 & .49913 \\
\hline
\end{tabular}

The t-observed value of 5.17 at 60 degrees of freedom is higher than the critical value of 2.66 at .01 levels of significance (Table 7). Based on these results it can be concluded that there is a significant difference between the mean scores of the experimental and control groups on the writing test. Thus, the first null-hypothesis as the negotiated syllabus does not significantly affect Iranian EFL learners' writing ability is rejected. The experimental group following the negotiated syllabus treatment - outperformed the control group on the writing test. It should be ,however, noted that the assumption of homogeneity of variances is not met. The probability associated with the Levene's $\mathrm{F}=$ 13.13 , i.e. .000 is lower than .05 . That is why the level of significance (alpha level) is reduced from .05 to .01 when reporting the results of the independent t-tests.

TABLE 7:

INDEPENDENT T-TEST POSTTEST OF SELF-EFFICACY BY GROUPS

\begin{tabular}{|c|c|c|c|c|c|c|c|c|c|}
\hline & \multicolumn{2}{|c|}{$\begin{array}{l}\text { Levene's Test } \\
\text { for Equality of } \\
\text { Variances }\end{array}$} & \multicolumn{7}{|c|}{ t-test for Equality of Means } \\
\hline & \multirow[t]{2}{*}{$\mathrm{F}$} & \multirow[t]{2}{*}{ Sig. } & \multirow[t]{2}{*}{$\mathrm{T}$} & \multirow[t]{2}{*}{ Df } & \multirow[t]{2}{*}{$\begin{array}{l}\text { Sig. (2- } \\
\text { tailed) }\end{array}$} & \multirow[t]{2}{*}{$\begin{array}{l}\text { Mean } \\
\text { Difference }\end{array}$} & \multirow[t]{2}{*}{$\begin{array}{l}\text { Std. Error } \\
\text { Difference }\end{array}$} & \multicolumn{2}{|c|}{$\begin{array}{l}95 \% \text { Confidence Interval } \\
\text { of the Difference }\end{array}$} \\
\hline & & & & & & & & Lower & Upper \\
\hline Equal variances assumed & 13.13 & 0.00 & 5.17 & 60.00 & 0.00 & 3.27 & 0.63 & 2.00 & 4.54 \\
\hline Equal variances not assumed & & & 5.74 & 52.79 & 0.00 & 3.27 & 0.57 & 2.13 & 4.42 \\
\hline
\end{tabular}

Investigation of the Second Research Question

In order to answer the second research question "Does a negotiated syllabus significantly affect Iranian EFL learners' writing self-efficacy?" the following steps were taken:

Post Test

For comparing the performance of the participants, the following test was administered to both groups.

Self-Efficacy measure 
An independent t-test was also run to compare the mean scores of the experimental and control groups on the posttest of self-efficacy after administering the treatment of negotiated syllabus to the former group. As displayed in Table 8 the experimental group with a mean score of 66.92 performed better on the posttest of self-efficacy than the control group $(\mathrm{M}=64.63)$.

TABLE 8:

DESCRIPTIVE STATISTICS OF SELF-EFFICACY MEASURE

\begin{tabular}{|l|l|l|l|l|}
\hline GROUP & $\mathrm{N}$ & Mean & Std. Deviation & Std. Error Mean \\
\hline Experimental & 26 & 66.9231 & 7.95449 & 1.56000 \\
\hline Control & 36 & 64.6389 & 6.04343 & 1.00724 \\
\hline
\end{tabular}

The t-observed value of 1.28 at 60 degrees of freedom is lower than the critical value of 2 at .05 levels of significance (Table 9). Based on these results it can be concluded that there was not any significant difference between the mean scores of the experimental and control groups on the posttest of self-efficacy. Thus, the data failed to reject the second null-hypothesis, as far as the self-efficacy notion was concerned. It should be noted that the assumption of homogeneity of variances was met. The probability associated with the Levene's $\mathrm{F}=.60$, i.e. .44 is higher than .05 .

TABLE 9:

INDEPENDENT T-TEST OF SELF-EFFICACY MEASURE BY GROUPS

\begin{tabular}{|c|c|c|c|c|c|c|c|c|c|}
\hline & \multicolumn{2}{|c|}{$\begin{array}{l}\text { Levene's Test for } \\
\text { Equality of } \\
\text { Variances } \\
\end{array}$} & \multicolumn{7}{|c|}{ t-test for Equality of Means } \\
\hline & \multirow[t]{2}{*}{$\mathrm{F}$} & \multirow[t]{2}{*}{ Sig. } & \multirow[t]{2}{*}{$\mathrm{T}$} & \multirow[t]{2}{*}{ Df } & \multirow[t]{2}{*}{$\begin{array}{l}\text { Sig. (2- } \\
\text { tailed) }\end{array}$} & \multirow[t]{2}{*}{$\begin{array}{l}\text { Mean } \\
\text { Difference }\end{array}$} & \multirow[t]{2}{*}{$\begin{array}{l}\text { Std. Error } \\
\text { Difference }\end{array}$} & \multicolumn{2}{|c|}{$\begin{array}{l}95 \% \text { Confidence Interval } \\
\text { of the Difference }\end{array}$} \\
\hline & & & & & & & & Lower & Upper \\
\hline Equal variances assumed & .603 & .441 & 1.285 & 60 & .204 & 2.28 & 1.77 & -1.27 & 5.83 \\
\hline Equal variances not assumed & & & 1.230 & 44.64 & .225 & 2.28 & 1.85 & -1.45 & 6.02 \\
\hline
\end{tabular}

\section{PET as a Post-test}

An independent t-test was run to compare the mean scores of the experimental and control groups on the PET as a post-test in order to prove that the effect of the negotiated syllabus to the improvement of the general proficiency of the experimental group. As displayed in Table 10 the experimental group with a mean score of 11.82 performed better than the control group $(\mathrm{M}=10.85)$ on the PET as a post-test.

TABLE 10: DESCRIPTIVE STATISTICS OF PET SCORES BY GROUPS

\begin{tabular}{|l|l|l|l|l|}
\hline GROUP & $\mathrm{N}$ & Mean & Std. Deviation & Std. Error Mean \\
\hline EXPERIEMNTAL & 26 & 11.8269 & 1.96439 & 38525 \\
\hline CONTROL & 36 & 10.8542 & 3.31252 & .55209 \\
\hline
\end{tabular}

The t-observed value of 1.34 at 60 degrees of freedom is lower than the critical value of 2.66 at .01 levels of significance (Table 11). Based on these results it can be concluded that there was not any significant difference between the mean scores of the experimental and control groups on the posttest PET. Thus, it can be claimed that the negotiated syllabus does not have any significant effect on the improvement of the general language proficiency of the experimental group. Then, similar to the self-efficacy, the participant's general proficiencydid not much change in light of the treatment. It should be noted that the assumption of homogeneity of variances was not met. The probability associated with the Levene's $F=7.69$, i.e. .01 is lower than .05 . That is why the level of significance (alpha level) is reduced from .05 to .01).

TABLE 11:

INDEPENDENT T-TEST OF PET SCORES BY GROUPS

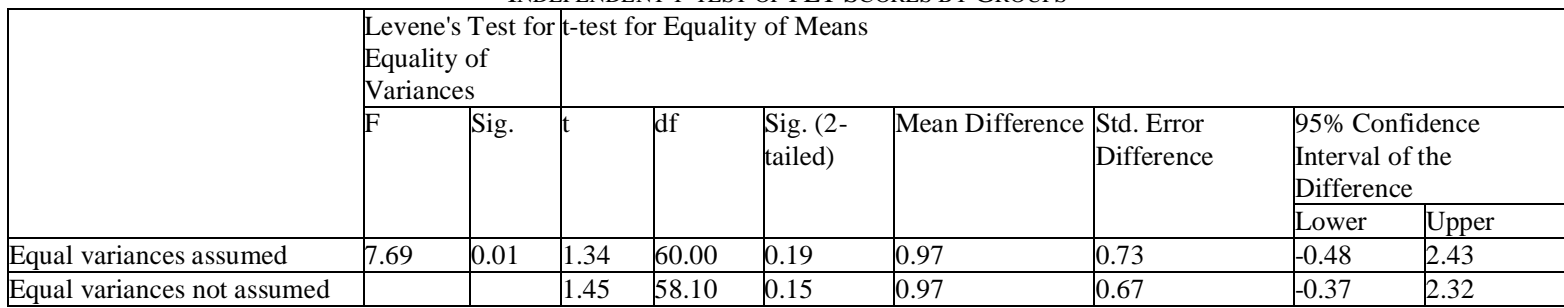

\section{Writing Tests}

A repeated measures ANOVA was run to compare the mean scores of the three writing tests administered to the experimental group. In order to observe any changes in the learners' writing achievement, three writing tests administered in the session 4, 6, and 8. The topics were selected through negotiation and the evaluation was done by the teacher. As displayed in Table 12, the F-observed value for comparing the mean scores of the students on the three writing test, i.e. 1.26 is lower than the critical value of 3.25 at 2 and 36 degrees of freedom. 
TABLE 12:

REPEATED MEASURES ANOVA THREE WRITING TESTS

\begin{tabular}{|c|c|c|c|c|c|c|c|}
\hline Source & & $\begin{array}{l}\text { Type III Sum of } \\
\text { Squares }\end{array}$ & $\mathrm{df}$ & Mean Square & $F$ & Sig. & Partial Eta Squared \\
\hline \multirow{4}{*}{ WRITING } & Sphericity Assumed & 2.772 & 2 & 1.386 & 1.267 & .294 & .066 \\
\hline & Greenhouse-Geisser & 2.772 & 1.920 & 1.443 & 1.267 & .294 & .066 \\
\hline & Huynh-Feldt & 2.772 & 2.000 & 1.386 & 1.267 & .294 & .066 \\
\hline & Lower-bound & 2.772 & 1.000 & 2.772 & 1.267 & .275 & .066 \\
\hline \multirow{4}{*}{ Error } & Sphericity Assumed & 39.395 & 36 & 1.094 & & & \\
\hline & Greenhouse-Geisser & 39.395 & 34.566 & 1.140 & & & \\
\hline & Huynh-Feldt & 39.395 & 36.000 & 1.094 & & & \\
\hline & Lower-bound & 39.395 & 18.000 & 2.189 & & & \\
\hline
\end{tabular}

Based on these results it can be concluded that there are not any significant differences between the mean scores of the students on three writing tests. As displayed in Table 13 the mean scores for the three writing tests are 15.76, 15.39 and 15.92 respectively.

TABLE13:

DESCRIPTIVE STATISTICS THREE WRITING TESTS

\begin{tabular}{|c|c|c|c|c|}
\hline \multirow[t]{2}{*}{ Tests } & \multirow[t]{2}{*}{ Mean } & \multirow[t]{2}{*}{ Std. Error } & \multicolumn{2}{|c|}{$95 \%$ Confidence Interval } \\
\hline & & & Lower Bound & Upper Bound \\
\hline WRITING1 & 15.763 & 607 & 14.487 & 17.039 \\
\hline WRITING2 & 15.395 & .542 & 14.257 & 16.532 \\
\hline WRITING3 & 15.921 & .428 & 15.022 & 16.820 \\
\hline
\end{tabular}

The reliability indices for the Pretest and posttest of self-efficacy are .88 and .81 respectively.

TABLE 14:

CRONBACH ALPHA RELIABILITY

\begin{tabular}{|l|l|l|}
\multicolumn{4}{c}{ CRONBACH ALPHA RELIABILITY } \\
\hline Self-Efficacy & Cronbach's Alpha & N of Items \\
\hline Pretest & 889 & 28 \\
\hline Posttest & 816 & 28 \\
\hline
\end{tabular}

\section{DISCUSSIONS AND CONCLUSION}

Much has been written on the practicality of syllabus negotiation in EFL education (e.g., Huang, 2006; Boomer et al., 1992; Breen \& Littlejohn, 2000; N. T. Nguyen, 2010; V. H. Nguyen, 2006). Similarly, studies have shown that classroom negotiation helps make the teaching program more responsive to learners' needs and wants (Nunan, 1988). Furthermore, many studies have shown a great relationship between self-efficacy and writing performance (e.g., Pajares\& Johnson, 1993; Pajares\& Johnson, 1996; Pajares, Miller, \& Johnson, 1999; Pajares\&Valiante, 1997; Wachholz\& Etheridge, 1996). In line with this trend, the results of the analyses revealed that in the area of writing there is a significant relationship between negotiated syllabus and writing ability. The negotiated syllabus has significant effect on learner's writing ability. This finding is consistent with the study done by Boomer et al. (1992), Breen and Littlejohn (2000), Candlin (2001), Hall (1999), Huang (2006), Neguyen (2011), and Nunan (2001) findings.

Contrary to the findings on the first research hypothesis, the results of the analyses revealed that in the area of writing there was not any significant difference between the mean scores of the experimental and control groups on the posttest of self-efficacy.Surprisingly, the results also indicated that there was not any significant difference between the mean scores of the experimental and control groups on the posttest PET. Thus, it can be claimed neither the general language proficiency nor the self-efficacy was significantly affected in light of the negotiation-based instruction. These findings are partially in contrast to those of Bandura $(1986,1997)$, who strongly believes that students' beliefs about their academic potentialities, or self-efficacy beliefs, are good prognosticators of their academic accomplishment and of their later career choices and decisions. Similarly, the result is different from what reported by Pajares' (2003) which concluded students' beliefs about their own writing competence, or self-efficacy beliefs as instrumental to their ultimate success. This state of affairs could also be attributed to unfamiliarity the syllabus to Iranian students who are by nature more in favor of and at ease with teacher-centered class. On the other hand, it is still a mystery whether the problem derive from the approach itself or from the teacher's and student's lack of experience. Moreover, one possible reason for such results may be partially attributable to the limitation of the time in this study as well. It is assumed that a bit longitudinal study employing some other types of introspection might generate different outcomes.

In short this study showed that those students who were under teaching with the help ofnegotiated syllabus had better retention of writing ability. As a matter of fact, negotiated syllable is one of the effective ways that can be applied in writing classrooms. Although the research literature strongly recommends that the self-belief about writing capabilities had a direct effect on writing outcomes, as the resultant statistics indicted that the two groups had no statistically significant difference on their writing self-efficacy and their general language proficiency at the intermediate level of language proficiency. 


\section{REFERENCES}

[1] Bandura, A. (1977). Self-efficacy: Toward a unifying theory of behavioral change. Psychological Review, 84,(2) $191-215$.

[2] Bandura, A. (1986). Social foundations of thought and action: A social cognitive theory. Englewood Cliffs, NJ: Prentice Hall.

[3] Bandura, A. (1995). Guide for constructing self-efficacy scales. Available from Frank Pajares, Division of Educational Studies, Emory University, Atlanta, GA 36322.

[4] Bandura, A. (1997). Self-efficacy: The exercise of control. New York: Freeman \& Co.

[5] Bandura, A., \& Locke, E. A. (2003). Negative self-efficacy and goal effects revisited. Journal of Applied Psychology, 88(1), 87-99.

[6] Blackman, P. (2008). A new science look at negotiating curriculum and classrooms. An International Journal of Complexity and Education, 5(1), 141-148.

[7] Bloor, M. \& Bloor, T. (1988). Syllabus negotiation: The basis for learner autonomy. In Brookes \& P. Grundy (Eds.), Individualization and autonomy in language learning (pp.62-74). London, England: Modern English Publications \& the British Council.

[8] Boomer, G., Lester, N., Onore, C. \& Cook, J. (1992). Negotiating the curriculum. Educating for the twenty first century. London: Falmer.

[9] Breen, M.P. (1987). Contemporary paradigms in syllabus design, part 1. Language Teaching, 20(2), 81-91.

[10] Breen, M.P., \& Little John, A. (2000). Classroom Decision-Making Negotiation and Process Syllabuses in Practice. U.K.: Cambridge University Press.

[11] Clarke, D.F. (1991). The negotiated syllabus: What is it and how is it likely to work? Applied Linguistics, 12(1), 13-28.

[12] Grunert, J. (1997). The course syllabus: A learning-centered approach. Bolton, MA: Anker Publishing Company.

[13] Hall, G. (1999). Redefining the syllabus: An investigation into whether syllabuses can meet learners' linguistic and social needs Retrieved October 4, 2003 from http://www.ling.lancs.ac.uk/groups/crile/crile45Hall.pdf.

[14] Hayes, J. R. (1996). A new framework for understanding cognition and affect in writing. In C.M. Levy \& S. Ransdell (Eds.), The science of writing: Theories, methods, individual differences and applications (pp. 1-27). Mahwah, NJ: Erlbaum.

[15] Lo, J., \& Hyland, F. (2007). Enhancing students' engagement and motivation in writing: The case of primary students in Hong Kong. Journal of Second Language Writing, 16, 219-237.

[16] Long, M. H. \& Crookes, G. (1993). Units of analysis in syllabus design: the case for the task. In G. Crookes \& S.M. Gass (Eds.), Tasks in a pedagogical context. Cleveland, UK: Multilingual Matters. 9- 44.

[17] Nguyen, N.T. (2011). Syllabus negotiation: A case study in a tertiary EFL context in Vietnam. Language Education in Asia.2 (1), 71-91.Retrived March 20, 2013 from http://dx.doi.org/10.5746/LEiA/11/V2/I1/A06/Nguyen.

[18] Nunan, D. (1994). Syllabus design. Oxford: Oxford University Press.

[19] Nunan, D. (1988). The Learner-Centered Curriculum. Cambridge, Cambridge University Press.

[20] Pajares, F. (2003). Self-efficacy beliefs, motivation, and achievement in writing: A review of the literature. Reading \& Writing Quarterly, 19, 159-172.

[21] Pajares, F., Miller, M. D., \& Johnson, M. J. (1999). Gender differences in writing self- efficacy beliefs of elementary school students. Journal of Educational Psychology, 91, 50-61.

[22] Pajares, F., \& Schunk, D. H. (2005). Self-efficacy and self-concept beliefs: Jointly contributing to the quality of human life. In H. Marsh, R. Craven, \& D.McInerney (Eds.), International advances in self-research, 2, 95-121.

[23] Pajares, F., \&Valianate, G. (2006). Self-efficacy beliefs and motivation in writing development. In C. A. MacArthur, S. Graham, \& J. Fitzgerald (Eds.), Handbook of writing research, 158-170. New York: Guildford Press.

[24] Pastorino, E. (1999). Students with academic difficulty: Prevention and assistance. APS Observer, 26, 10-11.

[25] Stevick, E.W. (1976). Memory, meaning and method. Rowley, M.A.: Newbury House.

[26] Stevick, E.W. (1980). Teaching language: a way and ways. Rowley, M.A.: Newbury House.

[27] Tuan, L. T. (2011). Negotiating tasks in EFL classrooms. Journal of Language Teaching and Research, 2(1), 13-25.

[28] White, R. (1988). The ELT curriculum, design, innovation and management. Oxford: Basil Blackwell.

[29] Zimmerman, B. J. (2000). Self-Efficacy: An essential motive to learn. Contemporary Educational Psychology, $25,82-91$.

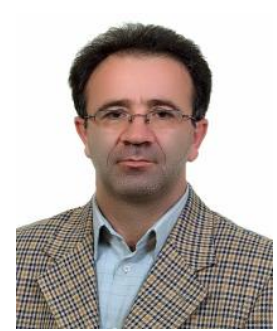

Gholam-Reza Abbasian was born in Ahar, I.R. of Iran in 1964, holds his PhD in applied linguistics from the Science \& Research Campus of IAU of Iran in 2005. Abbasian, as an assistant professor of TEFL at Imam Ali University \& IAU, has presented at (inter) national conferences, is the author \& translator of about 15 books, publisher of scholarly articles and offers psycholinguistics, language testing, \& syllabus design courses at MA level. Dr. Abbasian is the internal manager of JOMM, reviewer of Sage, FLA and GJER journals and a member of editorial board of JSSIR. He has received awards as top scholar and been nominated as the most successful teacher for six years.

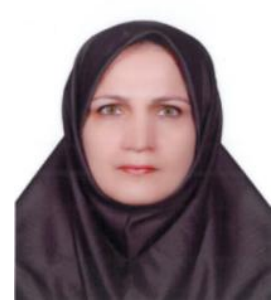

Parvin Malardi is an M.A. graduate student in TEFL from South Tehran Branch of Islamic Azad University. She has recently finished her M.A. studies at the above mentioned university. She has been teaching English for about 7 years in qualified English institutes in Tehran and Damavand, Iran. 